\title{
Foxp3+ regulatory T-cells and IL-2: the Moirai of T-cell fates?
}

\author{
Georg Gasteiger ${ }^{1 *}$ and Wolfgang Kastenmuller ${ }^{2 *}$ \\ 1 Immunology Program, Memorial Sloan-Kettering Cancer Center, New York, NY, USA \\ 2 The Laboratory of Systems Biology, National Institute of Allergy and Infectious Diseases, National Institutes of Health, Bethesda, MD, USA \\ *Correspondence: gasteigg@mskcc.org; kastenmullerw@mail.nih.gov
}

Edited by:

Kendall A. Smith, Weill Medical College of Cornell University, USA

Reviewed by:

Antonio A. Freitas, Institut Pasteur, France

Ria Baumgrass, German Rheumatism Research Centre Berlin, Germany

Shimon Sakaguchi, Osaka University, Japan

Regulatory T-cells $\left(\mathrm{T}_{\text {reg }}\right)$ have emerged as a crucial cellular checkpoint acting to prevent potentially harmful immune responses. Due to its highly diverse activities, regulating the immune system requires more than general suppression. Particularly, during the developing immune response to infection, $\mathrm{T}_{\text {reg }}$ need to balance the host reaction to achieve both an effective response against the invading pathogen as well as to prevent immunopathology from excessive or inappropriate activity. In this opinion article we discuss the dual roles of IL-2 as both a key inducer of $\mathrm{T}_{\text {reg }}$ activity and also a target of $\mathrm{T}_{\text {reg }}$ control during the acute phase of infection. We propose a model in which Foxp3+ regulatory T-cells dynamically "measure" IL-2 availability and restrict its access to effector T-cells, thereby controlling differentiation of these useful but potentially harmful cells.

CD4+ T-lymphocytes play a central role in orchestrating immune responses by modifying the functionality of other immune cells and guiding the qualitative features of a response to one optimal for resisting a particular microorganism. Besides augmenting both innate and adaptive immune responses, CD4+ T-cells limit excessive immune activation and immunopathology during infections. Among CD4+ T-cells, Foxp3+ regulatory T-cells $\left(\mathrm{T}_{\text {reg }}\right)$ are essential for the maintenance of peripheral tolerance (Kim et al., 2007; Lahl et al., 2007). These cells also modulate the responses to pathogens (Belkaid and Tarbell, 2009). A plethora of mechanisms for how $\mathrm{T}_{\text {reg }}$ exert their function have been suggested (Shevach, 2009; Josefowicz et al., 2012). However, there is still an ongoing debate as to which functions of $\mathrm{T}_{\text {reg }}$ are essential under which circumstances. Likely, $\mathrm{T}_{\text {reg }}$ function can be attuned to specific conditions and distinct "rules" govern $\mathrm{T}_{\text {reg }}$ behavior in the steady-state versus inflammatory environments, secondary lymphoid (SLO) versus peripheral organs, developing versus ongoing immune responses, or acute versus chronic infections, for example. In this article we focus on the function of $\mathrm{T}_{\text {reg }}$ in the SLO during a developing acute infection and, although several cytokines are relevant, we concentrate on IL-2 as a central platform that enables effective immune control, as it (1) links activation of effector and regulatory responses, (2) establishes a feed-back loop for T-cell expansion, and (3) allows control over T-cell differentiation and fate decisions, preserving memory formation.

\section{IL-2 IS A CENTRAL CYTOKINE FOR T-CELL ACTIVATION}

IL-2, originally discovered as a mitogenic factor for T-cells, is bound as a quaternary complex with CD25 (IL2R $\alpha$-chain), CD122 (IL2R $\beta$-chain), and CD132 (common $\gamma$-chain). The $\alpha / \beta$-heterodimer facilitates IL-2 capture with high affinity and, further stabilized by the $\gamma$-chain, forms a very stable complex which is terminated via receptor internalization rather than ligand dissociation (Smith, 2006). Upon activation by TCR interactions and additional co-stimulation via CD80/CD86, conventional T-cells ( $\mathrm{T}_{\text {conv }}$ ) produce IL-2 and upregulate CD25 expression, which enhances IL-2 capture and consequently IL-2 signaling, further promoting CD25 expression, T-cell activation, and proliferation. This feed-forward loop can lead to activation-induced cell death, but highly activated, proliferating T-cells also undergo apoptosis when acutely deprived of IL-2 signals. Therefore, IL-2 is a master regulator of T-cell activation, proliferation, and death, excellently reviewed in Malek and Castro (2010), Boyman and Sprent (2012).

\section{ACTIVATION OF T ${ }_{\text {REG }}$ THROUGH IL-2: ANTICIPATION AND SENSING OF EFFECTOR RESPONSES}

In contrast to conventional T-cells ( $\mathrm{T}_{\text {conv }}$ ), $\mathrm{T}_{\text {reg }}$ constitutively express CD25 (Sakaguchi et al., 1995) and have STAT5 phosphorylation in the steady-state, arguing for continuous or high frequency intermittent IL-2 signaling in the absence of infection. Indeed, IL-2 signals seem to be pivotal for $\mathrm{T}_{\text {reg }}$ survival because animals that lack IL-2, CD25, or CD122 are largely devoid of peripheral $\mathrm{T}_{\text {reg }}$ and suffer from severe autoimmunity (Sadlack et al., 1993; Suzuki et al., 1995; Willerford et al., 1995; Fontenot et al., 2005). $\mathrm{T}_{\text {reg }}$ do not produce IL-2 themselves when stimulated through the TCR and therefore rely on paracrine IL-2 for their maintenance. $\mathrm{T}_{\text {conv }}$ produce IL-2 upon activation and then gradually upregulate CD25. Since $\mathrm{T}_{\text {reg }}$ constitutively express CD25, they can sense and signal via IL-2 as soon as it is produced, assuming that these $\mathrm{T}_{\mathrm{reg}}$ are within suitable proximity to the cytokine secreting cells. Because IL-2 signaling further upregulates $\mathrm{CD} 25, \mathrm{~T}_{\text {reg }}$ can even increase their ability to capture IL- 2 as compared to $\mathrm{T}_{\text {conv }}$ which need to initiate CD25 expression post TCR-mediated activation (Feinerman et al., 2010). Indeed, it has been shown in vivo that $\mathrm{T}_{\mathrm{reg}}$ are the first cells to respond to IL-2 upon antigenic challenge of $\mathrm{T}_{\text {conv }}$ (O'Gorman et al., 2009). As the amount of IL-2 produced by T-cells correlates with the extent of co-stimulation from DC in vitro (Shahinian et al., 1993) and in vivo (Kastenmuller et al., 2011), it might reflect the magnitude of pathogen burden and the extent of innate stimulation. Therefore, $\mathrm{T}_{\text {reg }}$ "sense" the initiation of an adaptive immune response in a qualitative and potentially quantitative manner when responding to IL-2 signals derived from adaptive effectors. 
$\mathrm{T}_{\text {REG }}$ CONTROL THE AVAILABILITY OF IL-2 Given the relative abundance of $\mathrm{T}_{\mathrm{reg}}$ in SLO, where adaptive responses are initiated and IL-2 is being produced, it seems likely that the "sensing" of IL- 2 by $\mathrm{T}_{\text {reg }}$ consumes a significant amount of the totally available IL-2. In this scenario, the mere presence of $T_{\text {reg }}$ could reduce IL-2 availability and limit $\mathrm{T}_{\text {eff }}$ responses, without a need for active regulation (cytokine-sink model). Indeed, the presence of $\mathrm{T}_{\text {reg }}$ leads to substantial competition for IL-2, resulting in impaired proliferation of $\mathrm{T}_{\text {eff }}$ cells in vitro. Competition was further demonstrated in vivo, with a primary effect on the survival of $\mathrm{T}_{\text {eff }}$ and not on their proliferation (Pandiyan et al., 2007; Kastenmuller et al., 2011). $\mathrm{T}_{\mathrm{reg}}$ also control IL-2 production (Thornton and Shevach, 1998), either by directly acting on T-cells (Bodor et al., 2007; Vaeth et al., 2011) or indirectly, through DC (Onishi et al., 2008). The latter concept is based on in vitro evidence of a positive correlation between IL-2 production by Teff, the strength of ConA stimulation, and the amount of CD28 expression (Shahinian et al., 1993). $\mathrm{T}_{\text {reg }}$ express significant levels

\section{Activation of $T_{\text {reg }}$ and $T_{\text {Naive }}$}

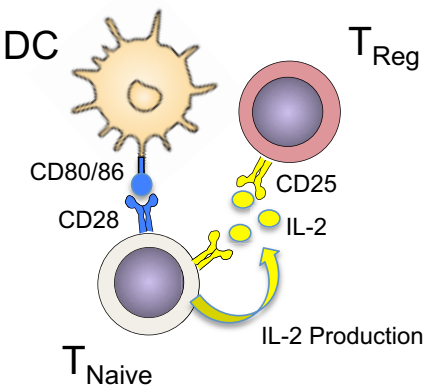

of surface CTLA- 4 on their surface and this molecule can directly block co-stimulatory molecules and CD28-CD80/86-interactions, or, via trans endocytosis, modulate the amount of CD80/86 that is displayed by DC (Wing et al., 2008; Qureshi et al., 2011). Importantly, the amount of CTLA-4 expressed on $\mathrm{T}_{\text {reg }}$ is again regulated by IL-2 signals. Consequently, $\mathrm{T}_{\text {reg }}$ control the level of co-stimulation through $\mathrm{CD} 80 / \mathrm{CD} 86$ surface expression not only during steady-state (Schildknecht et al., 2010), but, importantly, also during highly inflammatory processes such as viral infection (Kastenmuller et al., 2011).

Therefore, DC appear to constitute a platform on which both stimulation and regulation of conventional T-cells is executed, with IL-2 being a central mediator that activates both $\mathrm{T}_{\text {eff }}$ and $\mathrm{T}_{\text {reg }}$. Feed-back loops involving the constitutive high levels of CD25 on $\mathrm{T}_{\text {regs }}$ and the IL-2-promoted upregulation of CTLA- 4 on these cells operate in concert to restrict IL-2 availability to activated $\mathrm{T}_{\text {eff }}$ controlling their expansion, differentiation, and survival (Figure 1).

\section{Restriction of IL-2 by $\mathrm{T}_{\text {reg }}$}

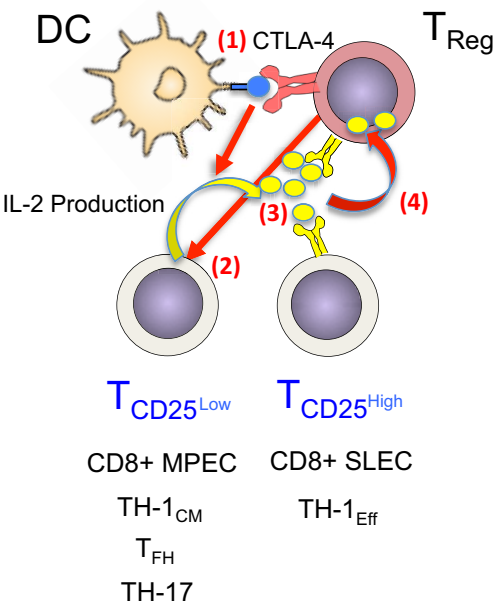

$T_{\text {BEG }}$ SELECTIVELY REGULATE EFFECTOR T-CELL RESPONSES BUT PRESERVE MEMORY DEVELOPMENT

Recently, the effects of IL-2 during acute infection have been further refined through analysis of the role of this cytokine in the various stages of CD8+ T-cell differentiation. After their initial activation and induction of CD25 expression, a subpopulation of CD8+ T-cells decrease CD25 levels and become unresponsive to further IL-2 signals, and, at the same time, upregulate the IL-7R $\alpha$-chain and develop into long-lived memory cells. This is in contrast to T-cells that are exposed to IL-2 for a prolonged period and maintain CD25 expression, undergo enhanced expansion, but differentiate into short-lived effector cells (SLEC) that are prone to apoptosis and severe population contraction after the peak of the response (Kalia et al., 2010; Obar et al., 2010; Pipkin et al., 2010). The recent development of genetic models allowing the specific depletion of Foxp $3^{+} \mathrm{T}_{\text {reg }}$ (Kim et al., 2007; Lahl et al., 2007) without blocking IL-2/CD25 interactions (Murakami et al., 2002; Suvas et al., 2003; Toka et al., 2004; Heit et al., 2008) enabled asking whether $\mathrm{T}_{\text {reg }}$ differentially affect these CD8+ T-cell subpopulations. Indeed, manipulating the numbers of activated $\mathrm{T}_{\text {reg }}$ in vivo impacted CD25 expression on activated CD8+ T-cells, indicative of altered IL-2 availability. This resulted in specific changes in numbers of SLEC while leaving the memory CD8+ T-cell compartment largely unaltered (Kastenmuller et al., 2011; McNally et al., 2011). Interestingly, the "window of opportunity" for the regulation of CD8+ T-cell responses by $\mathrm{T}_{\text {reg }}$ overlapped with the time of CD25 expression on CD8+ T-cells: depletion of $\mathrm{T}_{\text {reg }}$ cells as late as $\mathrm{d} 2-3$ post infection enhanced antigen-specific $\mathrm{T}$-cell numbers in a viral infection model, but depletion later than $\mathrm{d} 5$ (when CD8+ T-cells do not express CD25) failed to do so (Kastenmuller et al., 2011). In addition, enhanced expansion of SLEC in the absence of $\mathrm{T}_{\text {reg }}$ was abrogated through the neutralization of IL-2 (McNally et al., 2011). Therefore, by controlling the availability of IL-2, $\mathrm{T}_{\text {reg }}$ cells can act as rheostats that balance the differentiation and expansion of pathogen-specific CD8+ effector T-cells. Importantly, by selectively regulating SLEC over memory precursor T-cells, which rapidly seem to become independent of IL-2 signals (d2-3), $\mathrm{T}_{\text {reg }}$ can limit the extent of acute effector responses 
without blunting the development of longlived memory (Kastenmuller et al., 2011). However, once memory is formed and the host is re-challenged with a pathogen, $T_{\text {reg }}$ can again control the expansion of secondary effector cells adapted to the extent and requirements of the current infection.

$T_{P E G}$ MEDIATED RESTRICTION OF IL-2 AS A GENERAL MECHANISM TO REGULATE FATE DECISIONS IN T-CELLS

Beyond CD8+ T-cells, IL-2 likely serves as a central element that allows $\mathrm{T}_{\text {reg }}$ to regulate population size and differentiation of T-cells in general. A series of recent studies have established the role of IL-2 in CD4+ T-cell differentiation into $\mathrm{T}_{\mathrm{H} 1}, \mathrm{~T}_{\mathrm{H} 2}, \mathrm{~T}_{\mathrm{H} 17}$, and $\mathrm{T}_{\mathrm{FH}}$ cells (Liao et al., 2011; Boyman and Sprent, 2012). As with CD8+ T-cells discussed above, CD4+ T-cells segregate into $\mathrm{CD} 25^{\text {high }}$ and $\mathrm{CD} 25^{\text {low }}$ cells within the first days of a response to an acute infection, and prolonged IL-2 signals in CD $25^{\text {high }}$ cells leads to terminal differentiation and Blimp1 and T-bet upregulation in CD4+ effector cells. In contrast, $\mathrm{CD} 25^{\text {low }}$ cells gave rise to long-lived CXCR $5^{\text {high }}$ CCR $77^{\text {high }}$ T-bet ${ }^{\text {tow }}$ precursors of central memory cells, as well as CXCR5 ${ }^{\text {high }}$ Bcl $6^{\text {high }}$ follicular T-helper cells ( $\mathrm{T}_{\mathrm{FH}}$; Choi et al., 2011; Pepper et al., 2011). In line with this, $\mathrm{T}_{\text {reg }}$ limit the expansion of antiviral CD4+ during acute infection, yet do not influence the generation of neutralizing antibodies (Kastenmuller et al., 2011).

Therefore, by limiting excessive IL-2, $\mathrm{T}_{\text {reg }}$ might not only blunt $\mathrm{T}_{\text {eff }}$ response but also ensure the generation of $\mathrm{T}_{\mathrm{FH}}$ cells and consequently the development of appropriate humoral immunity early during acute infection, as IL-2 signals negatively regulate $\mathrm{T}_{\mathrm{FH}}$ differentiation (Ballesteros-Tato et al., 2012; Johnston et al., 2012). By restricting IL-2 during acute infection, $\mathrm{T}_{\text {reg }}$ might additionally enhance mucosal immunity and regeneration (potentially preventing superinfection) through promotion of $\mathrm{T}_{\mathrm{H} 17}$ generation, because production of this class of effector cells is inhibited by IL-2 (Chen et al., 2011; Pandiyan et al., 2011).

\section{SUMMARY AND PERSPECTIVE}

In summary, we propose a model in which IL-2 availability is a central factor that controls the magnitude and shapes the character of adaptive immune responses. $\mathrm{T}_{\text {reg }}$ control access of other T-cells to this crucial cytokine by limiting its production through interference with co-stimulatory molecule availability on DC, as well as by reducing its abundance through consumption. Importantly, this does not act to simply blunt the overall immune response but selectively impacts on T-cell fates that require larger amounts of IL-2. In contrast, other T-cell subpopulations, such as memory-precursors or $\mathrm{T}_{\mathrm{FH}}$, are not suppressed, allowing for the generation of cellular and humoral immunological memory to protect the host from future pathogen encounters (Figure 1). $\mathrm{T}_{\mathrm{reg}}$ are therefore not merely immunosuppressive, they actively participate in guiding the differentiation and fate decisions of other T-cells by regulating the availability of IL-2 in SLO. In this regard, $\mathrm{T}_{\text {reg }}$ controlling IL-2 availability remind us of the three Moirai (the incarnation of destiny in greek mythology) who controlled the thread of life and thereby directed the fate of individuals.

In addition to this early regulation of effector responses through IL-2, $\mathrm{T}_{\text {reg }}$ can undergo functional specialization that parallels the differentiation of conventional CD4+ T-cells in terms of transcription factor usage and expression of chemokine receptors important for homing to peripheral sites (Chaudhry et al., 2009; Koch et al., 2009; Zheng et al., 2009; Chung et al., 2011; Linterman et al., 2011). This differentiation might facilitate $\mathrm{T}_{\text {reg }}$ control of fully differentiated effector cells in infected tissues, which is likely to involve mechanisms distinct from regulating or competing for IL-2 (Soper et al., 2007), such as the production of immunosuppressive cytokines (Rubtsov et al., 2008) or cytotoxic molecules (Cao et al., 2007; Loebbermann et al., 2012).

Based on the emerging picture of selective control of effector T-cell fates, we speculate that interfering with $\mathrm{T}_{\text {reg }}$ function will help to optimize short-term immunotherapeutic approaches, but might be less promising to increase the efficacy of prophylactic vaccines aiming at the induction of longterm memory through $\mathrm{T}$ - and B-cells.

\section{ACKNOWLEDGMENTS}

This work was supported by the Intramural Research Program of NIAID, NIH, and DFG Ka 3091/1-1 to Wolfgang Kastenmuller. We would like to thank Dr. Ronald N. Germain for providing critical discussions, important input for this manuscript and great mentorship.

\section{REFERENCES}

Ballesteros-Tato, A., Leon, B., Graf, B. A., Moquin, A., Adams, P. S., Lund, F. E., and Randall, T. D. (2012). Interleukin-2 inhibits germinal center formation by limiting $\mathrm{T}$ follicular helper cell differentiation. Immunity 36, 847-856.

Belkaid, Y., and Tarbell, K. (2009). Regulatory T cells in the control of host-microorganism interactions $\left({ }^{*}\right)$. Annu. Rev. Immunol. 27, 551-589.

Bodor, J., Fehervari, Z., Diamond, B., and Sakaguchi, S. (2007). ICER/CREM-mediated transcriptional attenuation of IL-2 and its role in suppression by regulatory T cells. Eur. J. Immunol. 37, 884-895.

Boyman, O., and Sprent, J. (2012). The role of interleukin-2 during homeostasis and activation of the immune system. Nat. Rev. Immunol. 12, 180-190.

Cao, X., Cai, S. F., Fehniger, T. A., Song, J., Collins, L. I., Piwnica-Worms, D. R., and Ley, T.J. (2007). Granzyme $\mathrm{B}$ and perforin are important for regulatory $\mathrm{T}$ cellmediated suppression of tumor clearance. Immunity 27, 635-646.

Chaudhry, A., Rudra, D., Treuting, P., Samstein, R. M., Liang, Y., Kas, A., and Rudensky, A. Y. (2009). CD4+ regulatory T cells control TH17 responses in a Stat3dependent manner. Science 326, 986-991.

Chen, Y., Haines, C. J., Gutcher, I., Hochweller, K., Blumenschein, W. M., McClanahan, T., Hammerling, G., Li, M. O., Cua, D. J., and McGeachy, M. J. (2011). Foxp3(+) regulatory $\mathrm{T}$ cells promote $\mathrm{T}$ helper 17 cell development in vivo through regulation of interleukin-2. Immunity 34, 409-421.

Choi, Y. S., Kageyama, R., Eto, D., Escobar, T. C., Johnston, R. J., Monticelli, L., Lao, C., and Crotty, S. (2011). ICOS receptor instructs $\mathrm{T}$ follicular helper cell versus effector cell differentiation via induction of the transcriptional repressor Bcl6. Immunity34, 932-946.

Chung, Y., Tanaka, S., Chu, F., Nurieva, R. I., Martinez, G. J., Rawal, S., Wang, Y. H., Lim, H., Reynolds, J. M., Zhou, X. H., Fan, H.M., Liu, Z. M., Neelapu, S. S., and Dong, C. (2011). Follicular regulatory $\mathrm{T}$ cells expressing Foxp3 and Bcl-6 suppress germinal center reactions. Nat. Med. 17, 983-988.

Feinerman, O., Jentsch, G., Tkach, K. E., Coward, J. W. Hathorn, M. M., Sneddon, M. W., Emonet, T., Smith, K. A., and Altan-Bonnet, G. (2010). Single-cell quantification of IL-2 response by effector and regulatory $\mathrm{T}$ cells reveals critical plasticity in immune response. Mol. Syst. Biol. 6, 437.

Fontenot, J. D., Rasmussen, J. P., Gavin, M. A., and Rudensky, A. Y. (2005). A function for interleukin 2 in Foxp3-expressing regulatory T cells. Nat. Immunol. $6,1142-1151$.

Heit, A., Gebhardt, F., Lahl, K., Neuenhahn, M., Schmitz, F., Anderl, F., Wagner, H., Sparwasser, T., Busch, D. H., and Kastenmuller, K. (2008). Circumvention of regulatory $\mathrm{CD} 4(+) \mathrm{T}$ cell activity during cross-priming strongly enhances T cell-mediated immunity. Eur. J. Immunol. 38, 1585-1597.

Johnston, R. J., Choi, Y. S., Diamond, J. A., Yang, J. A., and Crotty, S. (2012). STAT5 is a potent negative regulator of TFH cell differentiation. J. Exp. Med. 209, 243-250.

Josefowicz, S. Z., Lu, L. F., and Rudensky, A. Y. (2012). Regulatory T cells: mechanisms of differentiation and function. Annu. Rev. Immunol. 30, 531-564.

Kalia, V., Sarkar, S., Subramaniam, S., Haining, W. N., Smith, K. A., and Ahmed, R. (2010). Prolonged interleukin-2R alpha expression on virus-specific $\mathrm{CD} 8+\mathrm{T}$ cells favors terminal-effector differentiation in vivo. Immunity 32, 91-103. 
Kastenmuller, W., Gasteiger, G., Subramanian, N., Sparwasser, T., Busch, D. H., Belkaid, Y., Drexler, I., and Germain, R. N. (2011). Regulatory T cells selectively control CD8+ T cell effector pool size via IL-2 restriction. J. Immunol. 187, 3186-3197.

Kim, J. M., Rasmussen, J. P., and Rudensky, A. Y. (2007). Regulatory T cells prevent catastrophic autoimmunity throughout the lifespan of mice. Nat. Immunol. 8, 191-197.

Koch, M. A., Tucker-Heard, G., Perdue, N. R., Killebrew, J. R., Urdahl, K. B., and Campbell, D. J. (2009). The transcription factor T-bet controls regulatory $\mathrm{T}$ cell homeostasis and function during type 1 inflammation. Nat. Immunol. 10, 595-602.

Lahl, K., Loddenkemper, C., Drouin, C., Freyer, J., Arnason, J., Eberl, G., Hamann, A., Wagner, H., Huehn, J., and Sparwasser, T. (2007). Selective depletion of Foxp3+ regulatory T cells induces a scurfy-like disease. J. Exp. Med. 204, 57-63.

Liao, W., Lin, J. X., and Leonard, W. J. (2011). IL-2 family cytokines: new insights into the complex roles of IL-2 as a broad regulator of $\mathrm{T}$ helper cell differentiation. Curr. Opin. Immunol. 23, 598-604.

Linterman, M. A., Pierson, W., Lee, S. K., Kallies, A., Kawamoto, S., Rayner, T. F., Srivastava, M., Divekar, D. P., Beaton, L., Hogan, J. J., Fagarasan, S., Liston, A., Smith, K. G., and Vinuesa, C. G. (2011). Foxp3+ follicular regulatory T cells control the germinal center response. Nat. Med. 17, 975-982.

Loebbermann, J., Thornton, H., Durant, L., Sparwasser, T., Webster, K. E., Sprent, J., Culley, F. J., Johansson, C., and Openshaw, P. J. (2012). Regulatory T cells expressing granzyme B play a critical role in controlling lung inflammation during acute viral infection. Mucosal Immunol. 5, 161-172.

Malek, T. R., and Castro, I. (2010). Interleukin-2 receptor signaling: at the interface between tolerance and immunity. Immunity 33, 153-165.

McNally, A., Hill, G. R., Sparwasser, T., Thomas, R., and Steptoe, R. J. (2011). CD4+CD25+ regulatory T cells control CD8+T-cell effector differentiation by modulating IL-2 homeostasis. Proc. Natl. Acad. Sci. U.S.A. 108, 7529-7534.

Murakami, M., Sakamoto, A., Bender, J., Kappler, J., and Marrack, P. (2002). CD25+CD4+ T cells contribute to the control of memory CD8+ T cells. Proc. Natl. Acad. Sci. U. S. A. 99, 8832-8837.

Obar, J. J., Molloy, M. J., Jellison, E. R., Stoklasek, T. A., Zhang, W., Usherwood, E. J., and Lefrancois, L. (2010). $\mathrm{CD} 4+\mathrm{T}$ cell regulation of $\mathrm{CD} 25$ expression controls development of short-lived effector CD8+ T cells in primary and secondary responses. Proc. Natl. Acad. Sci. U.S.A. 107, 193-198.

O'Gorman, W. E., Dooms, H., Thorne, S. H., Kuswanto, W. F., Simonds, E. F., Krutzik, P. O., Nolan, G. P., and Abbas, A. K. (2009). The initial phase of an immune response functions to activate regulatory $\mathrm{T}$ cells. $J$. Immunol. 183, 332-339.

Onishi, Y., Fehervari, Z., Yamaguchi, T., and Sakaguchi, S. (2008). Foxp3+ natural regulatory $\mathrm{T}$ cells preferen- tially form aggregates on dendritic cells in vitro and actively inhibit their maturation. Proc. Natl. Acad. Sci. U.S.A. 105, 10113-10118.

Pandiyan, P., Conti, H. R., Zheng, L., Peterson, A. C., Mathern, D. R., Hernandez-Santos, N., Edgerton, M., Gaffen, S. L., and Lenardo, M. J. (2011). CD4(+) CD25(+) Foxp3(+) regulatory T cells promote Th17 cells in vitro and enhance host resistance in mouse Candida albicans Th17 cell infection model. Immunity 34, 422-434.

Pandiyan, P., Zheng, L., Ishihara, S., Reed, J., and Lenardo, M. J. (2007). CD4+CD25+ Foxp3+ regulatory T cells induce cytokine deprivation-mediated apoptosis of effector CD4+ T cells. Nat. Immunol. 8, 1353-1362.

Pepper, M., Pagan, A. J., Igyarto, B. Z., Taylor, J. J., and Jenkins, M. K. (2011). Opposing signals from the Bcl6 transcription factor and the interleukin-2 receptor generate Thelper 1 central and effector memory cells. Immunity 35, 583-595.

Pipkin, M. E., Sacks, J. A., Cruz-Guilloty, F., Lichtenheld, M. G., Bevan, M. J., and Rao, A. (2010). Interleukin-2 and inflammation induce distinct transcriptional programs that promote the differentiation of effector cytolytic T cells. Immunity 32, 79-90.

Qureshi, O. S., Zheng, Y., Nakamura, K., Attridge, K. Manzotti, C., Schmidt, E. M., Baker, J., Jeffery, L. E., Kaur, S., Briggs, Z., Hou, T.Z., Futter, C. E., Anderson, G., Walker, L. S., and Sansom, D. M. (2011). Transendocytosis of CD80 and CD86: a molecular basis for the cell-extrinsic function of CTLA-4. Science 332, 600-603.

Rubtsov, Y. P., Rasmussen, J. P., Chi, E. Y., Fontenot, J., Castelli, L., Ye, X., Treuting, P., Siewe, L., Roers, A., Henderson, W. R. Jr., Muller, W., and Rudensky, A. Y. (2008). Regulatory T cell-derived interleukin-10 limits inflammation at environmental interfaces. Immunity $28,546-558$.

Sadlack, B., Merz, H., Schorle, H., Schimpl, A., Feller, A. C., and Horak, I. (1993). Ulcerative colitis-like disease in mice with a disrupted interleukin-2 gene. Cell 75, 253-261.

Sakaguchi, S., Sakaguchi, N., Asano, M., Itoh, M., and Toda, M. (1995). Immunologic self-tolerance maintained by activated $\mathrm{T}$ cells expressing IL-2 receptor alpha-chains (CD25). Breakdown of a single mechanism of self-tolerance causes various autoimmune diseases. J. Immunol. 155, 1151-1164.

Schildknecht, A., Brauer, S., Brenner, C., Lahl, K., Schild, H., Sparwasser, T., Probst, H. C., and Van Den Broek, M. (2010). FoxP3+ regulatory T cells essentially contribute to peripheral CD8+ T-cell tolerance induced by steady-state dendritic cells. Proc. Natl. Acad. Sci. U.S.A. 107, 199-203.

Shahinian, A., Pfeffer, K., Lee, K. P., Kundig, T. M., Kishihara, K., Wakeham, A., Kawai, K., Ohashi, P. S., Thompson, C. B., and Mak, T.W. (1993). Differential $\mathrm{T}$ cell costimulatory requirements in CD28-deficient mice. Science 261, 609-612.

Shevach, E. M. (2009). Mechanisms of foxp $3+$ T regulatory cell-mediated suppression. Immunity 30 , 636-645.
Smith, K. A. (2006). The structure of IL2 bound to the three chains of the IL2 receptor and how signaling occurs. Med. Immunol. 5, 3.

Soper, D. M., Kasprowicz, D. J., and Ziegler, S. F. (2007). IL-2Rbeta links IL-2R signaling with Foxp3 expression. Eur. J. Immunol. 37, 1817-1826.

Suvas, S., Kumaraguru, U., Pack, C. D., Lee, S., and Rouse, B. T. (2003). CD4+CD25+ T cells regulate virus-specific primary and memory $\mathrm{CD} 8+\mathrm{T}$ cell responses. J. Exp. Med. 198, 889-901.

Suzuki, H., Kundig, T. M., Furlonger, C., Wakeham, A. Timms, E., Matsuyama, T., Schmits, R., Simard, J. J., Ohashi, P. S., Griesser, H., Taniguchi, T., Paige, C. J., and Mak, T. W. (1995). Deregulated T cell activation and autoimmunity in mice lacking interleukin-2 receptor beta. Science 268, 1472-1476.

Thornton, A. M., and Shevach, E. M. (1998). CD4+ $\mathrm{CD} 25+$ immunoregulatory $\mathrm{T}$ cells suppress polyclonal $\mathrm{T}$ cell activation in vitro by inhibiting interleukin 2 production. J. Exp. Med. 188, 287-296.

Toka, F. N., Suvas, S., and Rouse, B. T. (2004). CD4+ $\mathrm{CD} 25+\mathrm{T}$ cells regulate vaccine-generated primary and memory CD8+ T-cell responses against herpes simplex virus type 1. J. Virol. 78 , 13082-13089.

Vaeth, M., Gogishvili, T., Bopp, T., Klein, M., BerberichSiebelt, F., Gattenloehner, S., Avots, A., Sparwasser, T., Grebe, N., Schmitt, E., Hunig, T., Serfling, E., and Bodor, J. (2011). Regulatory T cells facilitate the nuclear accumulation of inducible cAMP early repressor (ICER) and suppress nuclear factor of activated T cell c1 (NFATc1). Proc. Natl. Acad. Sci. U.S.A. 108, 2480-2485.

Willerford, D. M., Chen, J., Ferry, J. A., Davidson, L., Ma, A., and Alt, F. W. (1995). Interleukin-2 receptor alpha chain regulates the size and content of the peripheral lymphoid compartment. Immunity $3,521-530$.

Wing, K., Onishi, Y., Prieto-Martin, P., Yamaguchi, T., Miyara, M., Fehervari,Z., Nomura, T., and Sakaguchi, S. (2008). CTLA-4 control over Foxp3+ regulatory T cell function. Science 322, 271-275.

Zheng, Y., Chaudhry, A., Kas, A., Deroos, P., Kim, J. M., CHU, T. T., Corcoran, L., Treuting, P., Klein, U., and Rudensky, A. Y. (2009). Regulatory T-cell suppressor program co-opts transcription factor IRF4 to control $\mathrm{T}(\mathrm{H}) 2$ responses. Nature 458, 351-356.

Received: 15 April 2012; accepted: 11 June 2012; published online: 12 July 2012

Citation: Gasteiger G and Kastenmuller W (2012) Foxp3+ regulatory T-cells and IL-2: the Moirai of T-cell fates? Front. Immun. 3:179. doi: 10.3389/fimmu.2012.00179

This article was submitted to Frontiers in TCell Biology, a specialty of Frontiers in Immunology.

Copyright (๑) 2012 Gasteiger and Kastenmuller. This is an open-access article distributed under the terms of the Creative Commons Attribution License, which permits use distribution and reproduction in other forums, provided the original authors and source are credited and subject to any copyright notices concerning any third-party graphics etc. 